\title{
Perspectives
}

\section{Second-Language Acquisition and the Information Age: How Social Software has Created a New Mode of Learning}

Renaud J. Davies

We are presently witnessing a great shift in how young people learn and in the benefits that social software has to offer. New technologies can augment and build on traditional forms of social learning, giving birth to an improved and more multifaceted approach to knowledge acquisition that complements the current more general shift toward an increasingly technological world. The purpose of this article is not only to consider how social learning through the use of technology benefits learners, but also to investigate the implications of such learning and technology for curriculum development.

Nous témoignons actuellement d'un grand changement dans la façon dont les jeunes apprennent et sur le plan des avantages que nous procurent les logiciels sociaux. Les nouvelles technologies peuvent accroitre les formes traditionnelles de l'apprentissage social pour arriver à une approche améliorée et plus variée face à l'acquisition des connaissances et qui vient compléter l'évolution actuelle plus générale vers un monde de plus en plus technologisé. Cet article a comme objectif de considérer non seulement les avantages qu'offrent les logiciels sociaux aux apprenants, mais également les conséquences de ce style d'apprentissage et de ces technologies sur le développement des programmes d'études.

Today's students are different in their interaction with media from those of previous generations ... Schools must teach and nurture the collaborative and networking skills that students need in the socialnetworking Web 2.0 world. (Rosenfeld, 2007, p. 6)

\section{Social Learning}

Knowledge acquisition through social interaction is increasingly becoming a part of the curriculum in many areas of learning. This paradigm shift in knowledge acquisition is giving birth to new curricula that are more learnercentered and interactive. Furthermore, recent developments in technology are giving rise to a new kind of social learning that is in some aspects much more beneficial to students than traditional interactive learning in the class- 
room. In this article, I not only explore how social learning through the use of technology can benefit learners, but also investigate the implications of such learning and technology for curriculum development.

Before discussing the technological aspect of social learning, it is necessary to look at social learning in the more traditional sense, that is, learning through physical interaction requiring face-to-face communication and negotiation of meaning. The concept of interaction as an integral part of learning dates back to Socrates and can be seen in the works of more recent scholars such as Piaget (1970) and Vygotsky (1978) among others. Theorists are increasingly directing their attention to learning as something inextricably social. In fact many researches argue that interaction is the essence of the learning process (Mitchell \& Myles, 2004).

For the purposes of this article, I focus on the social constructivist perspective on knowledge acquisition. Social constructivism stresses the importance of social interaction and cooperation when learning. Thus constructivist research examines learners engaged in social practices and cooperative learning to see how such individuals construct meaning out of the input received during interactions. For example, Swain and Lapkin (1998) articulated a type of constructivist theory when stating, "Unlike the claim that comprehensible input leads to learning, we wish to suggest that what occurs in collaborative dialogues is learning. That is, learning does not happen outside performance; it occurs in performance" (p. 321).

Social constructivism owes much to its greatest contributor Vygotsky, and thus it is important to examine his contribution to constructivist theory. Vygotsky was born in in in 1896 Russia where he became a researcher and theorist of child development. Unfortunately, his writings did not begin to be published until the early 1960s because his work was disfavored by Soviet psychologists. Consequently, his theory and research has only recently become well known, particularly in the field of second-language acquisition (Mitchell \& Myles, 2004). Perhaps Vygotsky's most significant contribution to constructivist theory was his work relating to what he termed the Zone of Proximal Development (ZPD). Vygotsky (1978) defined the ZPD as:

The difference between the child's development level as determined by independent problem solving and the higher level of potential development as determined through problem solving under adult guidance or in collaboration with more capable peers. (p. 85)

Neo-Vygotskyans commonly use the scaffolding metaphor to describe the ZPD. During social learning, one's understanding may be scaffolded or raised by interaction with another person who is operating at a slightly higher level, closing the gap between a learner's existing developmental state and his or her potential development. In short, a student is able to do more with the help of adults or peers than if he or she were alone. Furthermore, 
social learning encompasses other benefits such as increased empathy, a sense of belonging, and better communication skills, all of which are supported by a cooperative community that in turn increases a participant's selfesteem and consequently, further reduces inhibition and other negative affective factors that may plague learners.

The key questions are whether learners can achieve all this through the use of technology and further, whether technology can improve the social aspect of learning. Many advocates of the traditional approach to learning would argue that technology takes away the real and tangible dimension of learning, leaving learners isolated and unable to communicate face to face. I argue that this does not have to be the case and that learning through technology does not necessarily mean doing away with the values associated with face-to-face communication. Rather, I stress that technology can augment and build on traditional forms of social learning, giving birth to an improved and more multifaceted approach to knowledge acquisition that complements the current more general shift toward an increasingly technological world.

\section{Social Learning in the Information Age}

McLoughlin and Lee (2007) discussed how information and communication technologies (ICT) are rapidly expanding and are building online communities where people can come together to learn and build knowledge cooperatively. As Pence (2006/2007) stated, "the Web is already morphing toward a new model, based on social interaction" (p. 347). Thus the Web is now opening a whole new avenue to learning. Web 2.0 technology designates the communicative form of the World Wide Web, which allows learners to become active members of an online program. Members not only view the content, but also have the power to change and shape it. Examples of such technology include such options as Web logs (blogs), Wikis, podcasts, social networking sites, and a plethora of others. Such social software includes currently popular interactive sites like Facebook and YouTube, as well as the online encyclopedia Wikipedia.

According to Dron, "social software ... is [where] control and structure can arise through the process of communication, not as a result of design, but as an emergent feature of group interaction" (cited by McLoughlin \& Lee, 2007 , p. 665). So what does this mean for education? Social software can also be seen as "pedagogical tools that stem from their affordances of sharing, communication and information discovery" (McLoughlin \& Lee, p. 666). McLoughlin and Lee define affordance as an "action that an individual can potentially perform in their environment by using a particular tool" (p. 666). In other words, such software has the capability to enhance how we educate people. Furthermore, Benson and Samaraswickrema (2007) aptly stated:

Use of social software such as blogs and wikis can empower learners and provide greater learner control through learner-learner interaction. 
When learners use the shared online space to build their learning environment collaboratively in a wiki, the choice made by the teacher to delegate control to the students in turn increases the students' choices within that context, and their ability to manage structure and dialogue. (p. 67)

Timothy E. Worth, a professor in learning technologies at Harvard's Graduate School of Education, called attention to what he termed an "evolution in education," stating that "Web 2.0 ... is a major paradigm shift in the way people think" (Riedel, 2008, para. 4). He stated, "thinking is now distributed ... across minds, tools and media, groups of people, and space and time" (para. 6). Learners of today are different in that they have access to new forms of learning due to technological change. We are currently in what has been termed the Information Age, which means that we are living in a time when people have unprecedented access to information and knowledge. The current generation in Canada and the United States, for example, are increasingly tech savvy and are accessing and learning information in a manner contrary to traditional top-down teaching methods. Today's learners, who have access to the Web and who use social software, often construct meaning through bottom-up, self-directed learning approaches. This is the new mode of learning. Thus it is imperative that curricula cater to this new mode of learning. According to Cuban (1992), "sources of changes largely come from outside the schools, yet policy makers, administrators, and practitioners have some measure of influence over how they respond to these external forces" ( p. 218). Educators are currently facing a tidal wave of technologically driven social and economic change that cannot be ignored and for which they consequently must be prepared. The question is how will these changes affect education in the future? Mills (2007) stated:

It's difficult to know how much change Web 2.0 technologies will bring to the school landscape. From the impact these applications have had in other arenas, superintendents and their deputies would do well to gain familiarity with the common tools that now are part of this likely revolution. (p. 5)

As a result, the type of knowledge that is most valued in society and how it is acquired are changing, so curricula must adapt to this changing landscape.

\section{The Benefits of Social Software}

It is important to address the issue of whether social software can in fact be a beneficial tool for social learning. To begin, traditional face-to-face group learning can be difficult to organize with adult learners in particular, and it does not always meet students' immediate needs. In contrast, online students can get immediate feedback or engage in quick research within seconds to 
gain further understanding. In addition, they have an enormous amount of information literally at their fingertips. Everhart (2006) stated, "some pedagogical improvements are either impossible to implement face-to-face or are significantly better online" (p.135). She noted that according to a recent study that examined the relationship between online environments and learning effectiveness, two aspects of teaching and learning were found to be better on line: interaction and learner-centeredness. Online discussion logs revealed an increase in both critical thinking and student participation. Based on such findings, Everhart aptly commented that online learning could "surpass faceto-face classrooms in providing learning experiences that are 'social, active, contextual, engaging and student-owned'"' (pp. 135-136).

Learner interaction through the use of social software places students on a level that goes well beyond the traditional classroom metaphor. Wikipedia, for example, allows people from around the world both to produce and to consume - or prosume, to reiterate McLoughlin and Lee (2007) —as well as mold, shape, combine, recombine, and share content collaboratively for the entire world to see and comment on. For example, wikis incorporate a history that shows teachers and researchers how writers have worked together, what changes have been made, who made the changes, and when. Eola and Oskoz (2010) stated that this "open editing and review structure of wikis ... makes them a suitable tool to support collaborative writing" and that

research into collaborative writing ... has shown that this pedagogical approach has great potential; it demands reflective thinking, helps learners to focus on grammatical accuracy, lexis and discourse, and it encourages a pooling of knowledge about the language (p. 51).

Another popular social software is the Web log or blog. Sun (2009) conducted a study of language-learners' speaking skills using voice blogs. Sun's findings suggested that blogs "constitute a dynamic forum that fosters extensive practice, learning motivation, authorship, and development of learning strategies" (p. 99). Blogs are ideal tools for global communication in that they can be easily created, accessed, linked, and referenced in other blogs. This social matrix has brought learning through interaction to a completely new level where individuals can scaffold on each other in a virtual environment that is continually shifting and turning in a global framework. In such an environment, learners may become higher risk-takers with lower inhibitions, allowing for greater confidence in exercising their intellect and their newly acquired knowledge. This latter point is especially important to adolescents. For example, Willis (2007) articulated well the benefits of social learning for young adolescents in particular:

A sense of belonging to a group where a student feels valued, builds resiliency. Resilient adolescents have greater success, social competence, 
empathy, responsiveness, and communication skills. They also demonstrate greater flexibility, self-reflection, and ability to conceptualize abstractly when solving problems. (para. 5)

Finally, one of the classic problems for traditional classrooms is the difficulty that a teacher may encounter in meeting the needs of all students. Students vary in their interests, learning styles, and learning strategies. Through the use of Web 2.0, technology students can actually help shape the curriculum to meet their own needs better and consequently become more autonomous learners. Similarly, teachers can better accommodate students by offering more options and tailoring the curriculum to individual students' needs. This can be accomplished much more easily when teachers do not have to teach a whole class simultaneously at a prescribed level.

\section{Incorporating Social Software into the Curriculum}

\section{Opportunities for learners}

To understand better how social software can be incorporated into the curriculum, I examine a few of Everhart's (2006) strategies for facilitating social learning. Everhart affirmed that her strategies could

provide scaffolding for social learning, offering specific methodologies that contribute to the benefits of engaging learners with each other. They are intended to help start discussions about why and how to participate in the evolution from course-centric to learning-centric pedagogical design. (p. 140)

Everhart's first strategy emphasizes the importance of group projects, wikis, portfolios, and discussion forums to encourage students' interaction. Next is to have an interesting thematic structure so as to engage learners in the activities and make learning more meaningful. Third, she highlighted the importance of links in the course material to guide learners to outside sources and/or to other parts of the course. She also stated that it is valuable to encourage the use of many types of social software tools such as chat, forums, blogging, and so forth. It is also important to have quick feedback from faculty and/or peers. The latter point is a significant part of social learning that is most advantageous when supported by a well-designed computer network. Finally, it is crucial to be aware that such software needs to be carefully designed and monitored so as to maximize its learning potential.

Appreciation of the advantages of using social software may be promoted by examining its actual use, which can be accomplished by reviewing instances of practical applications in current educational practice. To enumerate but a few examples, at the University of Connecticut, podcasts are used to record informal discussions by students following a lecture, to preview ma- 
terial that will be covered in a future lecture, and to review particularly important concepts from past lectures. At Osaka Jogakuin College in Japan, students are interviewed by their professor, enact role-plays, and create presentations, all of which are uploaded to the professor's bilingual podcast feed and blog for those studying Japanese or English as a foreign language. At the University of Michigan, learners collaboratively organize and display blog postings and bookmarks with keywords and tags (McLoughlin, 2007). In Australia, colleges of the New South Wales Institutes of Technical and Further Education make use of several wikis. The St. George College (n.d.) wiki, for example, offers online learning tools such as student blogs, ESL podcasts and video podcasts (vodcasts), digital stories, and numerous links to ESLrelated learning materials.

In addition, the Listening Plus online EFL course created by teachers at Casa Thomas Jefferson, a Binational Center in Brasilia, is another excellent example of how such technology can be implemented. Students in the course were required to use blogs, YouTube videos, and a VoiceThread about love stories around the world. After listening to and participating in conversations through blog postings, students helped create a VoiceThread to express their thoughts and ideas about the stories. A student in the course wrote, "the listening course was an excellent tool to practice and improve my English. We connected, interacted, listened, spoke, wrote and in my case learned a lot about Internet and computer" (Arena, 2010, p. 7).

\section{Applications for teachers}

It is important to mention that the technology discussed above is not applicable only to helping students learn interactively and socially. It may also be used to assist schools in designing their curriculum. In this connection, Waters (2007) observed, "Freed from the nuisances of paper-based methods, districts are making creative use of digital tools to move their curricular documents online, where educators can collaborate on course development and lesson planning" (para. 1). Waters discussed how the Amarillo Independent School District in Texas, comprising 52 schools, has recently adopted new technology to create and manage curriculum online. Members of the curriculum development team stated that with so many schools, it was difficult to get together for meetings and that going through hand-copy binders of curriculum objectives was extremely time-consuming.

However, through the use of wikis, blogs, forums, and other online technology, teachers can easily discuss curriculum issues and exchange ideas. One member of the Amarillo curriculum team stated, "The wiki makes it simple for that one teacher to get other teachers' input, which we're happy to have ... So all of a sudden, we're getting ideas from a lot more teachers than just the people who are on the committee" (Waters, 2007, para. 16). Waters went on to explain how technology can help teachers to share lesson 
plans online. A special program called the OnCourse planner automates much of the Amarillo district's lesson-planning process. It enables teachers to share recent and even two- or three-year-old lesson plans that individuals have plugged into the system from all over the district. The principals and other administrators have access and can discuss lesson planning with teachers. It is claimed that the system increases collaboration immensely among faculty members.

Similarly, in Akita, Japan, a wiki was created by assistant language teachers (ALTs) of English working for the Japan Exchange and Teaching (JET) program (Akita-ken, 2011). Because of the large size of the prefecture, ALTs are rarely able to meet to discuss teaching-related matters. So they constructed a wiki that would enable them to post questions, lessons, activities, and important links on teaching English. The wiki also encompasses information on living and working in Akita and Japanese-language study, not to mention links to other ALT wikis, Web sites, and forums connecting the entire JET community in Japan.

\section{Conclusion}

It has been argued that social interaction is increasingly becoming part of curricula and that many theorists have aptly voiced the importance of social interaction as an integral element in the learning process. Although the Web 2.0 era has only just begun, we are already witnessing a great shift in how today's young people learn, with a focus on the benefits that social software has to offer. These new technologies can augment and build on traditional forms of social learning, giving birth to an improved and more multifaceted approach to knowledge acquisition that complements the current more general shift toward an increasingly technological world. Increased empathy, a sense of belonging, better communication skills, and improved computer competence are among the many benefits that social learning has to offer. New technologies such as blogs, wikis, podcasts, social networking sites, and numerous others allow learners to communicate with a greater variety of students simultaneously and allow students to add to and even shape content collaboratively in an interactive world. Furthermore, students find themselves in a teacher-facilitated environment that can better accommodate their individual learning styles and that promotes learner autonomy. Finally, teachers and curriculum designers can use such software to design and share lesson plans and/or create curricula collaboratively through an online network that makes cooperation easier and more convenient. In brief, we are still witnessing only the beginning of a shift that will most certainly change not only how we teach, but how we construct and organize the curriculum itself. The field of second-language acquisition will benefit from embracing such technology and becoming a part of the ever-changing educational landscape. 


\section{The Author}

Renaud Davies works in Japan for the Akita Board of Education at the Prefectural Education Centre, where he organizes several teachers' conferences and seminars for English-language teachers working in public schools across the Akita Prefecture. In addition, he is a prefectural advisor for assistant language teachers working under the Japan Exchange and Teaching (JET) Program and regularly teaches English in several high schools. He received a Master of Education in curriculum studies and teaching English as a second language from Mount Saint Vincent University in Nova Scotia. Correspondence about this article may be addressed to Renaud J. Davies at renauddavies@hotmail.com.

\section{References}

Akita-ken. (2011). AJET community. Retrieved February 10, 2011, from: http:/ / www.akitajet.com/wiki/index.php?title=Main_Page

Arena, C. (2010). Listening Plus: A social approach to learning English online. TESL-EJ), 14 (2). Retrieved February 11, 2010, from: http://www.tesl-ej.org/pdf/ej54/int.pdf

Benson, R., \& Samarawickrema, G. (2007). Teaching in context: Some implications for elearning design. Proceedings Ascilite Singapore. Retrieved February 10, 2011, from: http:/ /www.ascilite.org.au/conferences/singapore07/procs/benson.pdf

Cuban L. (1992). Curriculum stability and change. In P.W. Jackson (Ed.), Handbook of research on the curriculum (pp. 216-247). New York: Macmillan.

Eola I., \& Oskoz, A. (2010). Collaborative writing: Fostering foreign language and writing conventions development. Language Learning and Technology, 14(3), 51-71.

Everhart, D. (2006). Evolving from course-centric to learning-centric: Portfolios, wikis, and social learning. Canadian Journal of University Continuing Education, 32(2), 133-146.

McLoughlin, C., \& Lee, M. (2007). Social software and participatory learning: Pedagogical choices with technology affordances in the Web 2.0 era. Proceedings Ascilite Singapore. Retrieved February 10, 2011, from: http:/ / www.ascilite.org.au/conferences/singapore07/procs/mcloughlin.pdf

Mills, B.L. (2007). The next wave now: Web 2.0. Education Digest, 73(4), 4-5.

Mitchell R., \& Myles, F. (2004). Second language learning theories (2nd ed.). London: Arnold.

Pence, E.H. (2006/2007). Preparing for the real Web generation. Journal of Educational Technology Systems, 35(3), 347-356.

Piaget, J. (1970). Piaget's theory. In P. Mussen (Ed.), Carmichael's manual of child psychology (pp. 703-732). New York: Wiley.

Riedel, C. (2008). Web 2.0: Helping reinvent education. The Journal. Retrieved February 14, 2011, from: http:/ / www.thejournal.com/articles/21907

Rosenfeld, E. (2007). Beginning the conversation about education 2.0. Teacher Librarian, 34(4), 6-7.

Sun, Y-C. (2009). Voice blog: An exploratory study of language learning. Language Learning and Technology, 13(2), 88-103.

St. George College. (n.d.). Sydney Institute Wikispaces. Retrieved January 16, 2011, from: http:/ / stgesol.sydneyinstitute.wikispaces.net/

Swain, M., \& Lapkin, S. (1998). Interaction and second language learning: Two adolescent French immersion students working together. Modern Language Journal, 82(3), 320-337.

Vygotsky, L. (1978). Mind in society: The development of higher psychological processes. Cambridge, MA: Harvard University Press.

Waters, K.J. (2007). Online collaboration: Curriculum unbound! T.H.E. Journal, 34(3), 40-48.

Willis, J. (2007). Coperative learning is a brain turn-on. Middle School Journal, 38(4). Retrieved February 20, 2011, from:

http://www.nmsa.org/Publications/MiddleSchoolJournal/Articles/March2007/Article1 /tabid/1287/Default.aspx 